\title{
BURSITIS OF THE SHOULDER IN COAL MINERS USING BORING MACHINES
}

BY

\author{
T. A. HUNT, O. P. EDMONDS, and R. H. P. FERNANDEZ \\ From the National Coal Board (East Midlands Division)
}

(RECEIVED FOR PUBLICATION MAY 18, 1954)

\begin{abstract}
The boring machine may in certain circumstances cause well-defined lesions of the skin and deeper structures of the shoulder loosely termed " beat shoulder". Although these lesions have not been specifically described many doctors in mining areas are aware of their association. We have examined clinically 35 full-time borers only three of whom presented themselves for treatment at a colliery medical centre. The rest were selected at random from six collieries which gave a wide range of work in different thicknesses of seam, a factor which was early realized to be important.
\end{abstract}

\section{The Machine and Working Environment}

The boring machine with trailing cable weighs approximately $40 \mathrm{lb}$. It is not a percussive tool but consists of a long drill driven by an electric motor having a substantial base against which the men push (Fig. 1). The electric motor is geared down from 2,400 r.p.m. to $750-500$ r.p.m. on the actual drill.

At intervals along the coal face holes are bored to depths varying from $2 \mathrm{ft}$. to $4 \mathrm{ft}$. 6 in., that is $6 \mathrm{in}$. less than the depth of coal cut by the coal-cutting machine. When the coal is cut near the floor the holes are bored near the roof or, alternatively, near

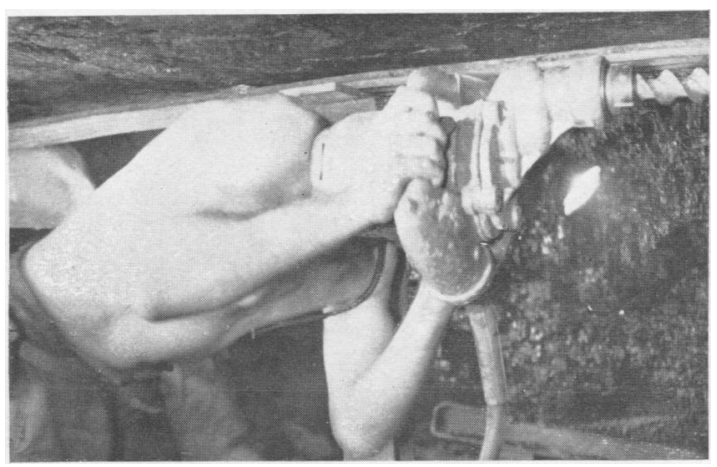

FIG. 1.-The boring machine. the floor when the coal is cut near the roof. The former is more common. Explosive is inserted into the hole and then fired to loosen the coal. A full-time borer will bore between 70 and 150 holes per shift of seven and a half hours. For top hole boring the borer presses his shoulder against the base of the boring machine, the relationship of this base to the shoulder region varying with seam thickness and the idiosyncrasy of the operator. For bottom hole boring the borer usually uses his feet.

When roadways are enlarged or developed boring occasionally is required, and here it is in stone, not coal.

The majority of cases we have described are of borers drilling in coal.

\section{Clinical Findings}

The exact relationship of the skin of the shoulder to the base plate of the machine plays a large part in determining the variance in the clinical picture, this in turn being related to the seam thickness and personal habits of the operator. The tissue changes in the region of the shoulder are in the skin (bruising, pigmentation, and sepsis) and in the formation of bursae, of which two types are described ; one lying near the point of the shoulder being superficial and subcutaneous, the other lying medially below the lateral third of the clavicle and partially deep to the medial fibres of deltoid. This latter bursa may be a continuation of the sub-deltoid bursa. Three cases were radiographed (one in Group II and two in Group III) and showed no abnormality.

\section{Cases Grouped According to Physical Signs}

The borers could be divided into four groups.

Group I.-Nine men had no signs or symptoms.

Group Il.-Eight men each had a large bursa situated below the lateral third of the clavicle, also showing diffuse skin changes. 
Group 11I.-Ten men each of whom had a bursa in the shoulder tip region, being subcutaneous and superficial to the acromial process but usually below it. The skin changes here were more localized than in Group II.

Group IV.- In this group of eight men there is a painful shoulder but no swollen bursa or skin changes.

\section{Clinical Features of Each Group}

The table is a summary of the chief features of each group.

Group I.-These men had neither subjective complaints nor any abnormality on physical examination. The average age of the group was 36 years and all worked in seam thicknesses of $4 \mathrm{ft}$. $6 \mathrm{in}$. and above, and in a seam of this thickness, although the shoulder is used, it is possible for a fellow workman to lend support to the base of the machine by standing behind the operator and pushing forward with his hands. The general feelings of the men supported this view. The average number of years spent boring was $3 \cdot 7$.

Group II.-The deltoid muscle takes its origin partly from the outer third of the calvicle, and in the eight cases seen in this group a bursa was emerging from the lower border of these clavicular fibres. The bursa was large and could have been an enlargement of the sub-acromial bursa (Fig. 2).

Skin changes were largely bruising and pigmentation, and we were informed that the bruising was most prominent at the week-ends when the men were resting from work. The skin changes were very

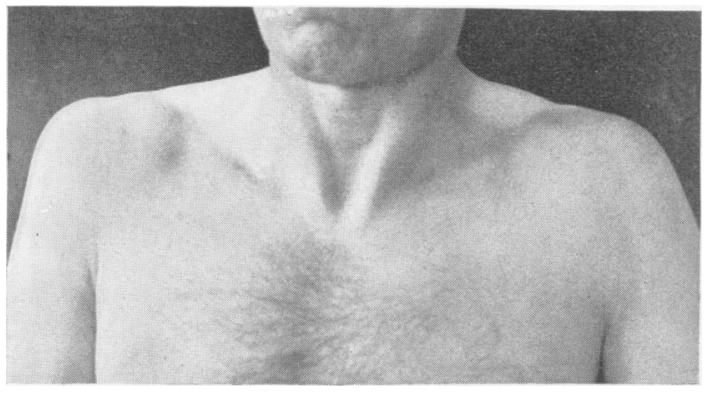

FIG. 2.-A bursa lying below the lateral third of the right slavicle.

diffuse and extended over the anterior aspect of the shoulder into the infra-clavicular region. Scratch marks in the region of the spine of the scapula, due to the apposition of the back to the roof during boring, were very well marked. These may become infected and so contribute to the inflammation of the bursa.

A typical history in this group was one attack of pain in the shoulder followed by swelling. We were fortunate to see two of these cases from the onset and to follow them up. During the acute, painful phase, which lasted only two to three days, in one case there was marked limitation of all shoulder movement, and in the other specifically painful abduction through the range $60^{\circ}$ to $120^{\circ}$ and on external rotation. Both these patients complained of a cold hand on the same side as the shoulder lesion, and on examination the hand was certainly cold. The swollen bursae persisted for three months and six months, but the men were back at work after an absence of only two and three weeks.

The other six cases were seen in the chronic state

TABLE

CLINICAL SUMMARY OF GROUPS STUDIED

\begin{tabular}{|c|c|c|c|c|c|c|c|c|c|c|}
\hline Group & $\begin{array}{l}\text { No. of } \\
\text { Men }\end{array}$ & $\begin{array}{c}\text { Average } \\
\text { Age } \\
\text { (years) }\end{array}$ & $\begin{array}{c}\text { Years } \\
\text { Boring }\end{array}$ & $\begin{array}{l}\text { Seam } \\
\text { Thickness } \\
\text { (ft. in.) }\end{array}$ & $\begin{array}{l}\text { Type of } \\
\text { Pain }\end{array}$ & Skin & Bursa & $\begin{array}{c}\text { Joint } \\
\text { Movement }\end{array}$ & $\begin{array}{l}\text { No. of } \\
\text { Hand } \\
\text { Symp- } \\
\text { toms }\end{array}$ & $\begin{array}{l}\text { Average } \\
\text { Time } \\
\text { Lost } \\
\text { per } \\
\text { Attack }\end{array}$ \\
\hline I & 9 & 36 & $3 \cdot 7$ & $\begin{array}{cc}4 & 6 \\
\text { and } & \text { over }\end{array}$ & - & - & - & - & - & - \\
\hline II & 8 & 40 & 12 & 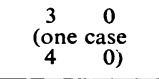 & $\begin{array}{l}\text { Single acute, } \\
\text { short attack }\end{array}$ & $\begin{array}{l}\text { Diffuse bruising, } \\
\text { pigmentation of } \\
\text { varying degree }\end{array}$ & $\begin{array}{l}\text { Deep subdel- } \\
\text { toid }\end{array}$ & $\begin{array}{l}\text { Affected dur- } \\
\text { ing acute stage } \\
\text { only }\end{array}$ & 4 & $\begin{array}{l}\text { Days } \\
\text { only }\end{array}$ \\
\hline III & 10 & 34 & 7 & $\begin{array}{cr}3 & 6 \\
(2 & \text { cases } \\
4 & 6)\end{array}$ & $\begin{array}{l}\text { Slight, worse } \\
\text { at work }\end{array}$ & $\begin{array}{l}\text { Marked local- } \\
\text { ized pigmenta- } \\
\text { tion, sepsis in } 3 \\
\text { cases }\end{array}$ & Superficial & - & 5 & $\begin{array}{l}\text { Days } \\
\text { only }\end{array}$ \\
\hline IV & 3 & 59 & 26 & $\begin{array}{cl}\text { Greater } & \text { than } \\
4 & 6\end{array}$ & $\begin{array}{l}\text { Continuous, } \\
\text { severe, better } \\
\text { at work }\end{array}$ & - & - & Marked fixity & 3 & Weeks \\
\hline IV & 5 & 49 & $7 \cdot 5$ & $\begin{array}{rr}4 & 6 \\
(2 & \text { cases } \\
3 & 0) \\
\end{array}$ & $\begin{array}{l}\text { One severe } \\
\text { attack }\end{array}$ & - & - & $\begin{array}{l}\text { Affected dur- } \\
\text { ing attack }\end{array}$ & 3 & Weeks \\
\hline Total & 35 & 48 & 9 & - & - & - & - & - & 15 & - \\
\hline
\end{tabular}


during which there is slight shoulder pain, insufficient to keep them off work, together with the swollen bursa, but no limitation of shoulder movement. The pain was sometimes worse in bed at night.

The average age of the men in this group was 40 years. Each man bored approximately 75 holes per shift, using his shoulder, and had spent 12 years boring. The seam thickness was $3 \mathrm{ft}$. in all cases except one ( $4 \mathrm{ft}$.) and in two cases the trouble arose immediately on transferring from a thicker seam to a seam $3 \mathrm{ft}$. in thickness. The other cases blamed poor quality of the bits which are fitted on to the end of the drill, or a particularly hard piece of coal.

Two cases in the group and one of the third group showed a localized patch of growing hair about the size of a five-shilling piece which, we were told, grew long and silky during their holidays. The significance of this is difficult to assess, but we felt that it was in some way related to the friction occasioned by the base of the boring machine.

Group III.-There were 10 men in this group, eight of whom came from one pit. The distinguishing features were well-marked skin changes and a welldefined subcutaneous bursa situated over the greater tuberosity of the humerus and the bicipital groove in the region of the shoulder tip. The bursa is well demonstrated in Fig. 3, being lateral and more

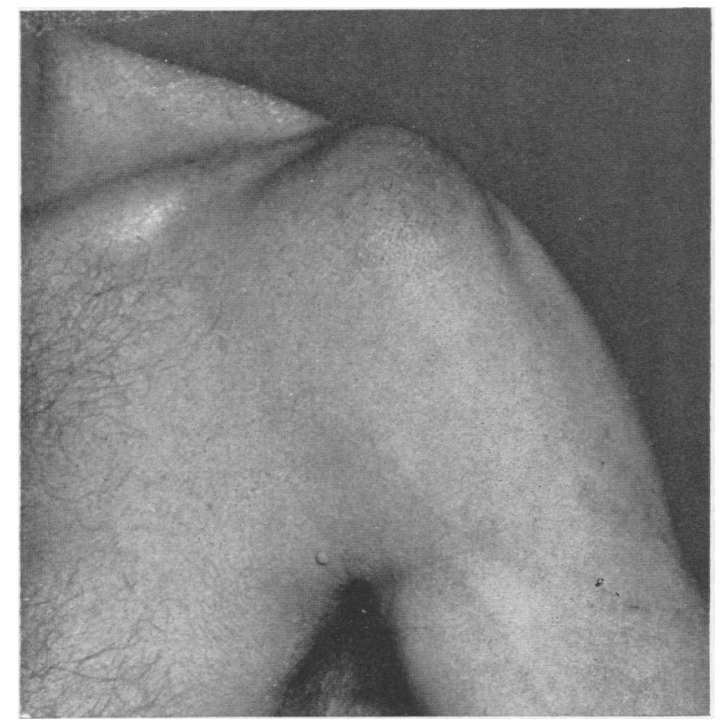

Fig. 3.-Subcutaneous bursa of the left shoulder, showing the coal particles embedded in the skin over the bursa.

superficial than the bursa in Group II. Fig. 4 shows superficial and deep bursae together in the same person. The superficial bursa on the shoulder tip has been partially aspirated and had no connexion with the deep bursa.

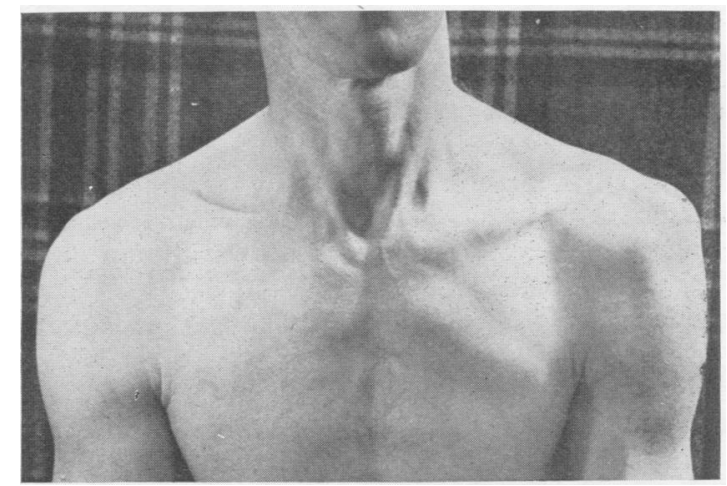

Fig. 4.-Both types of bursa in the left shoulder.

Sepsis is frequent in the group and the skin changes are well marked (Fig. 5).

It is suggested that this is an adventitious bursa which develops as a result of the frictional pressure of the "ram's head" (base of the boring machine). The history of these patients differs from those in

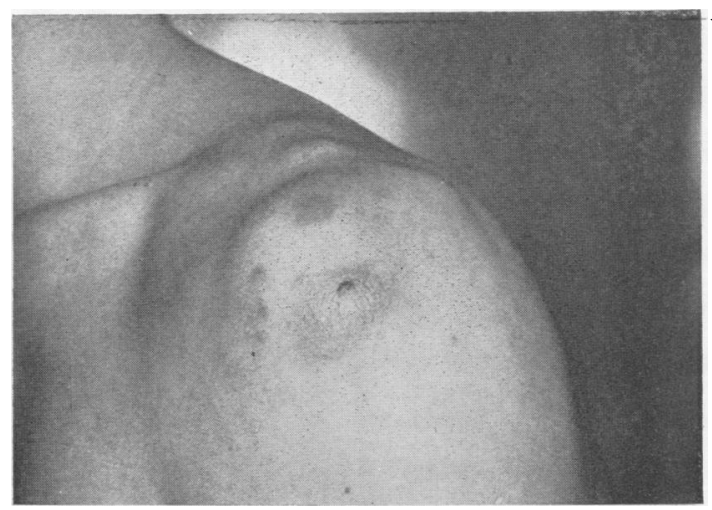

FIG. 5.-Skin sepsis over superficial bursa.

Group II. Three men complained only of slight soreness and two had slight pain only when boring, which passed off an hour or so after the shift. Two had intermittent attacks of pain occurring at monthly intervals, lasting a day or two, during their first two years of boring, but had no trouble since. Two others were still in the intermittent painful stage, and one man aged 54 years had developed continuous pain only during the past 12 months after boring for 14 years without symptoms. This latter type of pain is much more common in Group IV.

The average age of this group was 34 years, i.e., appreciably younger than Group II, and each man bored 80 holes per shift with his shoulder. Eight also bored a further 75 holes per shift using their feet 
(they work on a contract basis). This is mentioned because boring at this speed requires greater pressure, and friction is likely to be more intense. Each man has been boring on the average seven years. The seam thickness was $3 \mathrm{ft}$. 6 in. in eight of the cases, and $4 \mathrm{ft} .6 \mathrm{in}$. in two other cases.

Another notable feature was that eight men used their left shoulder, although they were all righthanded. The reason for this was that if the drill struck a particularly hard piece of coal the machine was thrown to the left and could do least damage to the face.

Group IV.-This is a miscellaneous group of eight men, in none of whom was there any skin or bursa changes on examination, but all complained of a painful shoulder. Three of them had had continuous pain in the shoulder for two, four, and five years. The pain was severe and extended down to the insertion of the deltoid and up to the trapezius muscle in the neck. The pain was better after an hour at work and most severe in bed at night. One man actually sleeps in a chair because he is unable to lie on the affected shoulder. In these three cases abduction and external rotation were severely limited and it is probable that they were cases of periarthritis or pericapsulitis of the shoulder.

The average age of these three men was 59 years, and each bored approximately 67 holes per shift. Together they had bored for 79 years. The pain in these cases was more severe than in the other groups and more time was lost.

The fourth case was seen during his first attack of pain after boring for seven years in rock and stone. The attack lasted three weeks and was a typical supraspinatus lesion. He worked in seams of greater thickness than $4 \mathrm{ft}$. 6 in. and had lost two weeks' work. Three other men had had similar attacks of pain, being unable to play darts or remove their shirts.

The average age of this group was 53 years, and it is doubtful if their symptoms can be specifically related to boring, as this type of lesion is so common in older people irrespective of their occupation (Nicoll, personal communication). It is possible, however, that boring may make the condition worse.

The last patient in this group is worthy of separate comment. He was aged 48 years and had been boring for seven years but had given up this work 18 months before because of a painful shoulder. The pain began from the first day of working, building up to a crisis approximately every month. Altogether he lost 252 working days in a period of seven years. The pain radiated down the radial border of the forearm, and, according to the patient, he lost his power of grip. Tingling and numbness appeared in the thumb and first two fingers of the hand from the first day of boring and increased in intensity coinciding with the crisis of shoulder pain. There were no physical signs when we examined him, but it is possible that this syndrome may have been occasioned by a functional abnormality of the thoracic outlet as in the two men in Group II who had a cold hand on the affected side.

\section{Hand Symptoms}

Those borers with no signs or symptoms referable to the shoulder made no complaint of their hands. Of the other 27 cases, 15 had subjective hand symptoms. Three of these men have already been mentioned and one other case had one spell of tingling and numbness of his right hand, which coincided with the attack of shoulder pain. Of the other 11 cases, deadness and numbness of the hands was a more frequent complaint than pain or tingling. In four cases it was bilateral and the following phrases are most expressive: "I suck them to life every morning upon getting out of bed." "I have to slap my hands on the side of the bed to restore them to life." "I often sleep with my hand hanging over the edge of the bed in order to keep it alive."

Apart from occurring in bed, these attacks were precipitated by reading the paper with the hand elevated and during and directly after a shift. In the other seven cases the symptoms were confined to the hand on the side of the shoulder which was used for boring, and there were no symptoms in the other hand. The micdie and ring fingers were most commonly affected.

These symptoms are presented in order to complete the picture of the hazards of the boring machine. The incidence of approximately $43 \%$ is sufficiently high to suggest that they are of occupational origin, but no explanation of their exact nature or the mechanism by which they are produced can be made from the results of our examination, which was not sufficiently comprehensive nor specifically directed with this object in view.

\section{Summary}

Thirty-five full-time borers have been examined and the results of the clinical findings are detailed.

A new adventitious bursa is described and was found in borers working mainly in seam thicknesses of $4 \mathrm{ft}$. and below.

We would like to thank Mr. E. A. Nicoll, C.B.E., F.R.C.S., consultant surgeon, for his help and advice in the preparation of this paper; Dr. J. Rogan, Chief Medical Officer of the National Coal Board, and Dr. J. Trefor Watkins, our Divisional Medical Officer, for their encouragement and guidance. 